\title{
BEYOND 'CLASH OF CIVILIZATIONS' AND 'GLOBAL WAR ON TERROR'
}

\author{
By: Supriyanto $A b d i *$
}

Abstrak

Artikel ini berusaba menjawab beberapa pertanyaan seputar bubungan dan kesesuaian antara Islam dan modernitas yang terus dimunculkan dan semakin diperdebatkan menyusul tragedi 11 September. Secara kbusus, artikel ini mengleaji kembali secara kritis teori "benturan peradaban" (clash of civilizations) dan penerjemabannya ke dalam kampanye pemerintab Amerika Serikat tentang "perang global melawan teror" (global wat on tertot). Argumen utama artikel ini adalah babwa paradigma "benturan peradaban" yang sangat terkait dengan proyek unilateral "perang global melawan teror" pimpinan Amerika Serikat secara konseptual menyesatkan dan secara empiris gagal menjawab persoalan radikalisme dan fundamentalisme Islam. Dikemukakan babuva ketimbang mengkampanyekan "benturan peradaban" dan menggunakan pendekatan yang unilateral dan militersitik terbadap persoalan-persoalan politik glabal, perbatian dan energi yang lebih semestinya ditujukan pada upaya untuk menjawab isuisu etis dan keadilan yang munoul dari polarisasi global dalam kekayaan, pendapatan dan kekuasaan.

حاول الكاتب أن ينيب الأسئلة حول الإسلام والقضايا العصرية وخصصوصا بعد هجوز المادثة

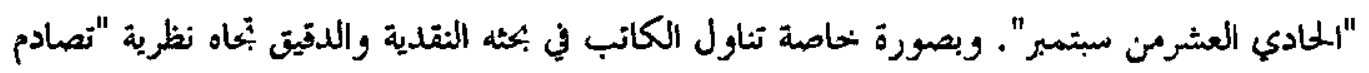

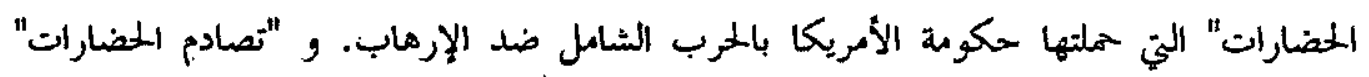
حسب الكاتب و"الحرب العالمي" التي يريدها ويقودها الأمريكا كائت فاشلة ومضلة. فمن الأفضلر,

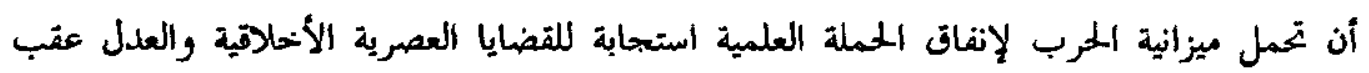
العولمة في الدول الأغنياء ودخلها وسلطاتها.

Keywords: clash of civilizations, Islam, modernity, fundamentalism and justice.

* Staf Pusat Studi Hak Asasi Manusia Universitas Islam Indonesia, e-madl: s_abdi77@yahoo.co.id 


\section{A. Introduction}

September 11 attacks on New York and Washington, allegedly carried out by Osama bin Laden-led radical Islamic organization, al-Qaida, and the subsequent major changes in global politics, marked primarily by the United States-led 'global war on terror', have generated many questions concerning the compatibility of Islam and modernity. Were the attacks, and the US response to them, a tangible evidence of 'the clash of civilizations'? Is Islam compatible with modernity? How do we understand and address Islamic fundamentalism? Is 'the global war on terror', unilaterally initiated and led by the US, a justifiable and appropriate response? How should modernity be conceived in this globalizing world?

This article will attempt to answer some of these questions. In so doing, it critically reviews the theory of 'clash of civilizations' and its translation or appropriation into 'the global war on terror'. It will argue that the highly inter-connected 'clash of civilization' paradigm and the US's unilateral project of 'global war on terror' are conceptually flawed and empirically fail to address the issue of Islamic fundamentalism. It also suggests that, instead of promoting 'a clash of civilizations' and deploying a unilateral, militaristic approach in dealing with terrorism and global politics in general, more attention and energy should be devoted into addressing the ethical and justice issues posed by the global polarization of wealth, income, and powet.

\section{B. The Translation of 'Clash of Civilizations' into 'Global War on Terror'}

Many observers tend to portray contemporary world politics in terms of civilizational conflict, an approach which has been populatized by Samuel Huntington. Years before the tragic event, Huntington predicted that the next world war, if there is one, will be a war between civilizations arguing that ideological cleavages were now being replaced by the fault lines of civilizations, reinforced by a revival of religion and culture as the identities that distinguish friend from foe. These cleavages, in his view, are ultimately reducible to that between 'the West and the Rest', and the threat to the West was primatily from a putative alliance of Islamic and Confucian civilizations. ${ }^{1}$

Several weeks after the events, he reaffirmed his theory suggesting that "bin Laden wants it to be a clash of civilizations between Islam and the West and that 'reactions to September 11 and the American response were strictly along civilizational lines". ${ }^{2}$ Echoing Huntington's theory, Fukuyama suggests the attacks was an assault against modernity and points out Islam as the one major world cul-

${ }^{1}$ Samuel P. Huntington (1993), "The Clash of Civilizations?" in Foreign Affairs, Vol. 72 No. 3, Summer, p. 7.

2 Btigitte Nacos (1003), The Terrorist Calculus Behind 9-11: A Model for Future Terrorism, Studies in 
ture that arguably does have some very basic problems with modernity. While he doubts that there is something inherent in Islam as a religion that makes it hostile to modernity, he suggests that "the Islamic world differs from other world cultures in one important respect: its repeated and increasing rejection not just to Western policies but the most basic principle of modernity itself, that of religious tolerance". In this sense, he explicitly rejects the view that politics had anything much to do with what happened and stresses instead the 'civilizational' gulf by suggesting that the present conflict is between modernity and what he calls 'Islamo-facism'."

Huntington and Fukuyama are not definitely the only supporters of clash of civilizations theory. The theory in fact gained a central and hegemonic position in wotld politics after it was endorsed by political forces in the United States. While Ptesident George W. Bush has insisted that this administration is not launching a wat against Islam, his vatious govemmental policies and discourses of 'global war on tertor' are basically premised on the clash of civilizations. ${ }^{5}$ Since the September 11 attacks, the Bush administration has consistently claimed that they are engaged in a battle between 'good' and 'evil' and then invited the world to choose either to join the forces of good, the upholders of civilization and civility, or conversely, be counted among evildoers, the dwellers in the darkness of barbarity. The Bush administration, therefore, "was perpetuating an old and well-established colonial habit: dividing the world into the civilized and uncivilized, and declaring that the white man's burden was to civilize the world, by force if necessary". 6

Contrary to the assumption of most writing on global govetnance suggesting that international relations have to be conducted on a shared, multilateral, basis, the theory of 'clash of civilizations' and 'global war on terror' tend to 'emphasize the call for a hegemonic power to maintain the world order. The idea of 'hegemonic power' in world politics resembles a strong current in the literature on managing the world economy that argues for 'hegemonic stability', i.e. for the view that unless one country is willing and able to play a leading role, to set the rules and punish wrongdoers, the system will not work. The lack of any such hegemonic system, it is argued, will be the source of the world's financial and economic instability. The same line of thinking then is deployed in arguing that the pursuit of international goals -peace, prosperity, safety from ecological collapse, etc. - requires that some

Confict and Terrorism, p. 12. See also Matk B. Salter (2002), Barbarians and Civilizations in International Relations, London: Pluto Press, pp. 164-165.

${ }^{3}$ Francis Fukuyama (2002), "History and September 11". in Ken Booth and Tim Dunne (eds),

Worlds in Collision: Terroi and the Future of Global Order, New York: Palgrave McMillan, Pp. 31-32.

+ Tariq Ali (2002), The Clash of Fundanienitalisms, London: Verso, pp. 283-284.

${ }^{5}$ Khaled Abou el-Fadl (2002), "The Orphan of Modemity and the Clash of Civilizations", in Global Dialogue, Vol 4, No 2, Spring, p. 3.

${ }^{6}$ Ibid, p. 3. 
states play a leading role and ensure that others follow the rules. ${ }^{7}$

The main protagonist of 'clash of civilizations', Samuel Huntington, for example, clearly subscribes this kind of argument. As some of his critics demonstrate, his interest in the continued dominance of the 'Euro-American West,' which cannot be allowed to become multicultural (a multicultural America is an impossibility, he says, because a non-Western America is not American), is all too transparent. Hans Kung, for instance, illustrates Huntington' strong support of 'the West superiority' in the following terms:

He is very obviously keen to 'maintain Western technological and military superiority over other civilizations': in clash of civilizations Europe and America will bang together or hang separately'. In this way, further self-authorized military interventions by the United States and the United Kingdom without a NU mandate can be easily justified. ${ }^{8}$

In this regard, Huntington actually maintains and perpetuates the hegemonic realist current of international relations thinking. One of the earliest and most powerful expressions of realist assumptions about human nature and human interactions was enunciated by Thomas Hobbes in the seventeenth century. Hobbes developed an argument for unified sovereignty and authoritarian rule that led to what Keohane refers to as 'Hobbes's dilemma'. As Keohane puts, Hobbes' dilemma 'encapsulated the existential tragedy that results when human institutions collapse and people expect the worst from each other'. ${ }^{9}$ Hobbes's dilemma can be summarized in two propositions: First, since people are rational calculators, self-interested, seeking gain and glory, and fearful of one another, there is no security in anarcby. Concentrated powet is necessary to create order; otherwise, 'the life of man (is) solitary, poor, nasty, brutish and short'. ${ }^{10}$ Second, but precisely because people are self-interested and power-loving, unlimited power for the rules implies a predatory, oppressive state. This is what Martin Wight calls 'the Hobbesian paradox': 'The classic Realist solution to the problem of anarchy is to concentrate power in the hands of a single authority and to hope that this despot will prove a partial exception to the rule that men ate bad and should be regarded with distrust."11

7 Fred Halliday (2000), "Global Governance: Prospects and Problems" in David Held and Anthony McGrew (eds), The GlobalTransformation Reader, Malden, MA: Blackwell Publisher, p. 433.

${ }^{8}$ Hans Kung (1999), "Inter-Cultural Dialogue versus Confrontation" in Hentik Schmieglow (ed), Preventing the Clash of Civilizations: $A$ Peace Strategy for the Twenty-First Century, New York: St. Martin's Press, pp. 102-103.

"Robert O. Keohane (2000), "Sovereignty in International Society" in David Held and Anthony - McGrew (eds), The GlabalTransformation Reader, Maiden, MLA: Polity and Blackwell Publisher, p. 111.

${ }^{10}$ Ibid., p. 111.

"Ibid., p. 111. 


\section{The Fallacies of 'Clash of Civilizations' Theory}

Much has been said about the fallacies of a clash of civilization theory. In attacking the theory, most critics, however, variably agree in pointing out the underlying essentialist, unitary, and patochial premises as the main problem of it. Edward Said, one of the most prominent critics of essentialist reading of culture, criticizes the theory for experiding "thousands of words without a single teference to people, periods and events". ${ }^{12}$ In a similar vein, others criticize the theory for its reductive reference to Islam as a surtogate idea or usage for unitary faith, history, or socioeconomic condition ${ }^{13}$ while Mahmood Mamdani describes the theory as the contemporary version of what he calls 'culture talk', a kind of talk which assumes that it is culture (modernity), and not politics, that serves as "a dividing line between those in favour of a peaceful, civic existence and those inclined to terror". ${ }^{14}$

In what follows, the essay will further elaborate the fallacies of these essentialist, unitary and parochial premises of the theory. Firstly, with its basic premise that culture or civilization, including and especially Islam, is a coherent sociological and political entity, the clash of civilizations theory tends to overlook the complex nature of religious movements and ignore the intimate relationship between religious discourses and different and changing socio-political contexts. As some authors succinctly argue, there.are many Muslim societies whose historical variation cannot be unified in terms of common cultural items. ${ }^{15}$ This is because, they argue, Muslim discourses and the actors who articulate them are historically situated. Ismail Salwa, for instance, suggests that "meanings and action are determined in relation to material condition such as institutional relations and the actors position of power". ${ }^{16}$ As a consequence, she concludes;

"the scripture should not be-used to attribute bomogeneity to Muslim societies since its interpretations and their insertion into particular contexts with varied meaning/power effects presents a multitude of discourses that must be accounted for reference to the powver

${ }^{12}$ Edward Said (2002), "Impossible Histories: Why the many Islam cannot.be simplified" in Harper's Magazine, July.

${ }^{13}$ Fot this kind of analysis, see, for example, John L. Esposito and John A. Voll (1996), Islam and Democray, New York and Oxford: Oxford University Press; Fred Halliday (2003), Islam and the Myth of Confrontation: Religion and Politics in the Middle East, London: IB Tauris; Amyin B. Sojo (ed) (2002), Givil Society in the Muslim W'orld: Contemporary Perppectives, London: IB Tautis; Salwa. Ismail (2003), Retbinking Islamist Politics, Culture, the State and Islamism, London: IB Tauris.

14 Mahmood Mamdani (2003), Good Muslims, Bad Muslims: America, the Cold War and the Roots of Terror, New York: Pantheon Book, p. 17.

${ }^{15}$ See Talal Asad (1983), "Ideology, Class and the Otigin of the Islamic State" in Economy and Socity, Vol. 9, No. 4; November; Aziz Al-Azmeh (1993), Islams and Modernities, London, New Yotk: Verso; and Sami Zubaida (1986), Islam, the People and the State, Routledge: London.

${ }^{16}$ Salwa Ismail (2003), Islamist Politics, Culture, the State and Islamism, London: IB Tautis, pp. 16-17. 
position at stake"."7

In a more elaborate account, Talal Asad has persuasively argued that: Islamic religious, legal, political ideologies do not bave an essential significance which moulds the minds of believers in a predictable way. They are part of changing institutions, and discourses which can be, and often are, contested and reconstituted. To understand the autboritative limits of such contestations one must focus on religious discourses witbin speciffic bistorical situations, and not on a supposedly original Islamic ideology. ${ }^{18}$

Secondly, in telation to Islam, the theory does not only perceive Islam as an unchanging unitary, monolithic category, it also grossly reduces the complexity of Islamic discourses and traditions into what has come to be called the jibadist vision, the supremacist, exclusive and intolerant religio-political discourses promoted by certain radical Islamic gtoups. In other wotds, ignoring the plutality of Islamic discourses and Muslim politics, the clash of civilization thesis supports and validates instead the puritan and exclusive discourse of radical of fundamentalist Islamic movements as the only representation of Islamic civilization. ${ }^{19}$

The clash of civilizations theory thus symbolically and discursively validates and enhances the fundamentalist construction of Islatn as the antithesis of the West. In this respect, the theory provides a discursive framework and ideological construction trough which the leaders of Islamist movements can criticize Western dominance, as they want, from a civilizational rather than a political viewpoint. As Tibi remarks, the contention of Muslim fundamentalist is not based on as assumption of egalitarian and pluralist definitions of cultures and civilizations. They want, rather, to reverse the hegemonic power situation in favour of Islam. ${ }^{20}$ In other wotds, "they envisage a reversal leading to the emergence of structures that shift the centre of power in decentring the West to pave the way for a global dominance of

${ }^{17}$ Ibid, pp. 16-17.

${ }^{18}$ Talal Asad, "Ideology, Class and the Origin of the Islamic State" in Economy and Society, Vol. 9, No. 4, November, p. 467.

${ }^{19}$ As many observes, one of essential discourse of Islamic fundamentalism is a binary vision by which Islam and the West are seen fundamentally incompatible and mutually exclusive. In this vision, the world is cleatly divided into two definable camps: those who are the true followers of Islam and those who are not. One of leaders of radical Islamic movement, Sayyid Qutb, foe example, suggests that Islam and the West wete incompatible and co-existence between the two was impossible. In similar way with Huntingtori, Qutb explicitly presented the struggle for Islam in terms of clash of civilizations, with Islam identified as the only truly civilized society, in conflict with false or 'incomplete' civilizations. See John L. Esposito and John. O Voll (2000), "Islam and the West: Muslim Voices of Dialogue" in Millenium:Journal of International Studies, Vol. 29, No. 3, p. 614.

${ }^{20}$ Bassam Tibi (2001), Islam Between Culture and Politics, Palgrave: McNillan, pp. 91-92. 


\section{Islam".21}

Thirdly, as a result of this essentialist tendency, the 'clash of civilizations' thesis fails to capture the socio-religious complexity in today's Muslims. The theory is much too simplistic to account for the complex dynamics of the Muslim world. Failing to perceive civilization as an amalgam of social forces and ideas that is continually changing and developing in response to challenges both from within and from without, the theory fails to acknowledge that he Muslim wotld has, in recent years, seen rising voices of moderation, religious toletance, democratic social movements, and human rights. ${ }^{22}$ These developments show that there is no inherent clash between Islam and the West. As Bikhu Parekh rightly argues, "some strands within Islam fit nicely with some strands within the West, and on some readings of them, Islamic and Western civilizations share much in common". ${ }^{23}$ Islam, in other words, is not a homogeneous entity with an unchanging essence. There are in fact "many Islams just as there are many Wests". ${ }^{4}$

What is more important to note, however, is that the struggle for reform and democracy has been a major component of contemporary Islamic resurgence. As argued by Hefner, while some Muslims called for a totalizing transformation of the social order based on an ideal of pristine unity identified with the first generation of Muslim believers, there is a remarkable effort underway in many countries to give Muslim politics a civic, pluralist, and even democratic face, marked primarily by "the resistance to etatist and essentializing interpretation of politics and calling for a plutalistic organization of state and society". ${ }^{25}$ As also well documented by Esposito, the call for greater liberalization, democratization and the creation of institutions of civil society has become a common and widespread historical transformation in the Muslim world. ${ }^{26}$ The claims of the clash of civilizations, with its essentialist tendency, however, reduce this complex social and historical dynamics into "essentialized and artificially coherent categories and thus only serves to obfuscate

${ }^{21}$ Farid Esack (2003), "In Search of Progressive Muslims" in Omid Safi (ed), Progressive Mustims on Gender, Pluralism and Justice, Oxford: One World Publisher, p. 80.

${ }^{22}$ Mahmood Monshipoury (2003), "The Semptember 11 Tragedy and the Muslim World: Living with Memory and Myth" in Journd of Church and State, Waco: Winter, Vol. 45, Iss. 1, p. 15.

${ }^{23}$ Bikhu Patekh (2002), "Terrorism or Intercultural Dialogue" in Ken Booth and Tim Dunne (eds), Worlds in Collision: Terror and the Future of Global Order, New York: Palgrave McMillan, p. 275.

${ }^{24}$ Ibid., p. 275; See also Al-Azmeh (1983), Islams and Modernitits, London: Verso. p. 4.

${ }^{35}$ Robert W. Hefner (ed) (2005), Remaking Muslim Politics, Princeton: Princeton University Press,

${ }^{26}$ See John L. Esposito and John A. Voll (1996), Iskm and Democrag, New York and Oxford: Oxford University Press anid Esposito (2003), "Islam and Civil Society" in John L. Esposito and Francois Burgat (eds), Modernizing Islam: Religion and the Public Spbere in the Middle East and Europe, London: Hurst\&Company. 
the real dynamics of the struggle between interpretative communities over who gets to speak for Islam and how". ${ }^{27}$

\section{Understanding Islamic Fundamentalism}

Addressing the problem of religious fundamentalism within the paradigm of clash of civilization with its essentialist and unitary premises is thus more likely to fail. More attention therefore needs to be paid to broader political or ideological concerns that either breed fundamentalism or ate invoked to fire it among Muslims.

In this regard it is important to note that fundamentalism is not purely Islamic phenomenon. Rather, it is a global fact that, as Karen Armstrong notes, is shated by all major faiths in response to modemity and secularization. One important point here is that all religious fundamentalisms, including Islamic fundamentalism, is an essential part of the modern scene and wherever modernity takes root, a fundamentalist movement is likely to emerge in conscious teaction to it. Fundamentalism, in other words, exists in "a symbiotic telationship with a coercive secularism". ${ }^{28}$

The close relationship between fundamentalism and modernity is important in understanding and defining all forms of fundamentalism, including Islamic fundamentalism. One important featute which can be drawn form this intimacy is that fundamentalism implies an awareness and fear of decreasing certain fundamental values and, therefore, there is a need for a return and restoration. It is in this context that Appleby, whose authoritative work in conjunction with Martin Marty has become a major source on global religious fundamentalism, finds that religious fundamentalism, generally speaking, refers to 'an identifiable pattern of religious militancy in which self-styled true believers attempt to artest the erosion of religious identity by outsiders, fortify the borders of religious community, and create viable alternatives to secular structures and processes". ${ }^{29}$

As part of global religious fundamentalism, Islamic fundamentalism can be understood in this general meaning. In this framework, John $\mathrm{O}$. Voll rightly define Islamic fundamentalism as "a distinctive mode of response to major social and cultural change introduced either by exogenous or indigenous forces and perceived as threatening to dilute or dissolve the cleat lines of Islamic identity."30 More specifically, Sami Zubaida perceives Islamic fundamentalism as "modern political move-

${ }^{27}$ Khaled Abou el-Fadl, op. ait.

${ }^{28}$ Karen Arsmtrong, p. 141.

29 Gerrie ter Haar (2002), "Religious Fundamentalism and Social Change: A Comparative Perspective" in Gerrie ter Haar and James J. Busuttil (eds.), The Freedorn to Do God's IVill: Religious Fundamentalism and Social Change, Routledge: London, New York, p. 5.

${ }^{30} \mathrm{John}$ O. Voll (1991), "The Heritage of Islamic Revival in Yvonne Yazbeck Haddad; The Revivalist Literature and the Literature on the Revival: An Introduction" in Yvonne Yazdeck Haddad et. all, The Contemporary Islamic Revival, Greenwood Press: New Yotk, Westpott. 
ments and ideas, mostly oppositional, which seek to establish, in one sense or another, an Islamic state modelled on a 'sacred history' of the original political community established by the Prophet Muhammad and maintained by his four successors". 31

Historically, Islam has always served as a vehicle for the expression of sociopolitical and economic dissent, particularly in times of crisis; and its idealistic and egalitarian character has provided the impetus for protest and even rebellion. ${ }^{32}$ Perhaps, more than any other religion, Islam has a militant potential and to tends to lend itself to express protest. From its very foundation, Islam had has a marked reform and protest character. ${ }^{33}$ In this context, some Muslim scholars, best represented by Khurshid Ahamd, argue that modern Islamic movement, including its fundamentalist form, is part of an overall Islamic historical pattern, known as tajitd, and is, consequently, "a perennial phenomenon in Islamic history and therefore not particularly new or modern." ${ }^{34}$ Islamic renewal has a long history within the Muslim experience. In principle, "tajdid (renewal) does not depend upon the existence of a challenge from the Western world; it has occurred in many times and places before the expansion of the West". ${ }^{35}$

The rise of Islamic fundamentalism, however, should also be viewed in the broader framework of the relationship between Muslim countries and the West. It is important to note here that, as any other Islamic movements, fundamentalism has been conditioned and influenced by the interaction between Europe and the Mus$\mathrm{lim}$ world.$^{36}$ Islamic fundamentalism, therefore, should be perceived as a socio-religious phenomenon evolving mainly in reaction to the Western thrust into the Muslim world. ${ }^{37}$ More specifically, Islamic fundamentalism is to be read as a protest against Western dominance and self-defence against Western encroachment on Islamic identity. ${ }^{38}$ In the words of Hisham Sharaby, Islamic fundamentalism, "was a psychosocial phenomenon taking from under European domination and in direct reaction to it". 39

With this in mind, it is important to note that, as Abou Al-Fadl suggests, the

${ }^{31}$ Sami Zubaida (1986), Islam, the People and the State, Routledge: London, p. 38.

${ }^{32}$ Mahmud A. Faksh (1997), The Future of Islam in the Middle East, Praeger: London, p. 23.

${ }^{33}$ Jacques Waardenburg (2002), Islan: Historical, Social and Political Perspective Walter de Gruyter: Berlin and New Yotk, p. 365.

${ }^{3}$ Cited in Ibrahim Abu Rabi' (1996), Intellectual Origins of Islamic Resurgence in the Modem Arab World, State University of New York Press: New York, p. 54.

${ }^{35}$ John. O. Voll, op. ait., p. 23.

${ }^{36}$ Bruce Lawtence (1998); Shattering the Mytb: Islam bejond Vialence; Princeton University Press: Princeton, p. 33.

${ }^{37}$ Ibrahim Abu Rabi', op. cit., p. 54.

${ }^{38}$ Jacques Waardenburg (2002), op. cit., p. 365.

${ }^{39}$ Ibrahim Abu Rabi', op. cit., p. 52. 
predominance of the theology of power within modern Islam, which is in his view a direct contributor to the emergence of highly radicalized Islamic groups, such as Taliban or al-Qaida, is "far from being authentic expression of inherited Islamic paradigms, or a natural outgrowth of the classical tradition". ${ }^{40}$ As el-Fadl notes, ...these groups, and their impulsive and reactive mode of thinking, are a by-product of colonialism and modernity. These bighly dissonant and defensive modes of thinking are disassociated from the Islamic civilizational experience with all its richness and diversity, and they invariably end up reducing Islam into a single dynamic - dynamic of power."

Seen from this perspective, the events of September 11 and other Islamic extremisms, as some observers have asserted, were caused not by cultural or religious differences or by American attempts to introduce democracy and human rights into the region, but rather by a myriad of historical and contemporary factors. Moreover, other causes of the attack cannot be divorced from the broader context of U.S. foreign policy in the Middle East, including U.S. support for Israel and for the region's pro-Western but corrupt regimes-not to mention U.S. involvement in a number of historical conflicts in the region. As rightly pointed out by An-Na'im, far from a clash of civilizations, the conflicts between Islamic groups and the United States stem not from value or civilizational confrontation, but from the failure of these governments, whose leadership relies exclusively on U.S. support, to bring about political, social, and economic development. ${ }^{42}$ In this sense, the fallacy of the thesis is clear in that the attacks were motivated by specific political, security and human rights grievances against the foreign policy of the United States, tather than by an irrational, generalized Islamic hostility to so-called 'Western civilization' as such. In this light, September 11 attacks and its aftermath is more about "the difference of power" between the two sides of the conflict and theit allies, tegardless of cultural/religious affiliation, than "the power of difference" between what so-called Islamic and Western civilizations. ${ }^{43}$

\section{E. A Clash of Fundamentalisms}

The rejection to the underlying essentialist, unitary and parochial premises of a clash of civilizations theory, however, should not be confused with the desperation to distance religion and, more specifically Islam, from violence or terrorism. It

to Khaled Abou el-Fadl op. cit., p. 84.

"1 Ibid.

42 Mahmood Monshipoury (2003), op. cit., p. 15.

${ }^{43}$ Abdullahi Ahmed An-Na'im (2002), "Upholding International Legality Against Islamic and American Jihad"' in in Ken Booth and Tim Dunne (eds), Worlds in Collision: Terror and the Future of Global Order, New York: Palgrave McNillan. 
is important to note here, as argued by a leading progressive Muslim Farid Esack, that the Qur'an is as open to diverse readings as any other texts and that the Muslims responsible for terrorist attack may have been inspired by it. As he notes,

The tendency of some Muslim commentators, who present themselves as the 'authentic' interpreters of Islam, to persistently declare that Islam means 'peace' and ihat 'Osama bin Ladin was not a Muslim", Wababism and fundamentalism bave notbing to do with "true Islam" falls into the same fallacy of a clash of civilizations theory in presenting "true Islam" as a concrete immutable set of ideas and beliefs, while others became the "inauthentic usurpers" of this set of beliefs.

What is rejected therefore is the assertion that violence, radicalism, tertorism or fundamentalism is intrinsically Islamic, but not the possibility of Islam, as any other religious traditions, being used as justification of these acts. At the same time, however, the possibility of Islam being interpreted within an exclusivist, supremacist lens should be understood in its intimate relationship with certain socio-political contexts. In this sense, Islamic fundamentalism is not the only fotm of fundamentalism and its existence is better seen as a response or teaction to other forms of fundamentalism. In relation to this, it is not hard to see that the US-led promotion and campaign of 'freedom', 'democracy' and 'free market', which assumes their principles to be a self-evident and universal truth or norm and hence dismisses alternative worldviews or ideologies as abnormal, deviant, irrational, and "fundamentalist" threat, is another form of fundamentalism. ${ }^{45}$

It is in this light that the collision at the Twin Towers is better seen, as Esack argues, as "the clash of two religious fundamentalisms: a reckless, incorrigible, fundamentalist, and all-pervasive religion of the Market on the one hand, and a fierce, angry, and vicious fundamentalist driven by pathological, deluded - but nevertheless religious - individuals on the other". According to Esack, both are fundamentalism in the sense that, like all forms of fundamentalism, "they are obsessed with a single truth as understood by it, demonizing of all others who refuse to get behind its truth". 46

Central to the rejection of a clash of civilization theory is therefore a multiple critique that makes it possible to identify similarities among fundamentalist positions - which must include the self - understanding of the US as the "Chosen Nation' and the neo-liberal fundamentalism that leads to blind faith in the market mechanism, two of its most blatant, non-Islamic examples. ${ }^{47}$ In other words, what is

" Farid Esack, op. cit., p. 80.

'5'John L. Esposito (2003), op. cit.

${ }^{16}$ Farid Esack; op. cit., p. 84.

${ }^{47}$ Buck-Morss, Susan (2003), Can There Be a Global Left, Thinking Past Terror, London, New York:Verso, p. 102. 
needed is a theory or paradigm that engages and challenges all the ideologies and institutions of injustice and inequality in various communities. This hegemony, according to one Muslim scholar, "comprises a multitude of forces, among them the oppressive and environmentally destructive forces of multi-national corporations whose interests are now linked with those of neo-imperial, unilateral governments". ${ }^{48}$

\section{F. Towards Global Governance and Global Justice}

The debate on Islamic fundamentalism, and how it should be dealt with, therefore, should be incorporated into tecent debates and demonstrations about the policies and procedures of international trade and financial organizations which have assumed the emergence of more global governance and justice. Central to these debates is the question of whether global regulatory regime will represent solely the interests of the world's most powerful actors or can include the voices and interests of the global majotity in transparent and accountable institutions. In response to this question, there has been increasing global awareness that leaders and citizens all over the world should envision a global rule of law and should try to shame and pressure the United States to act more in conformity with such a vision. ${ }^{49}$ As David Held argues, "what is needed is a movement for global, not American, justice and legitimacy, aimed at establishing and extending the rule of law in place of war and fostering understanding between communities in place of tertot". ${ }^{50}$

For this to happen, a multicultural global public sphere would need to be dialogical, not only in terms of content, through encouraging interchanges between different civilizational traditions, but also in form, by interrogating and respecting a range of different cultural notions of the public, citizenship, representation, human rights and democracy. It is in this sense that, as argued by Featherstone, "one of central tasks of out time is the translation of human rights from globalized liberalism, the freedom of the marketplace, into a genuinely cosmopolitan project based on inter-cultural dialogue". ${ }^{51}$

Instead of being captivated by the 'clash of civilizations' scenario, therefore, we should take the cultural-religious dimension of world politics seriously without imposing it on all other dimensions. As rightly argued by Kung;

${ }^{48}$ Omid Safi (2003), 'Introduction: The times they ate changin' a Muslim quest for justice, gender equality and pluralism" in Omid Safi (ed), Progressive Muslims on Justice, Gender and Pluralism, Oxford: One World Publication, p. 3.

"D Daniele Archibugi and Irish Marion Young (2003), "Envisioning A Global.Rule of Law" in James P. Sterba (ed), Terrorism and International Justice, New York: Oxford University Press, p. 160.

${ }^{50}$ David Held (2002), "Triolence, Law and Justice in A Global Age" in Craig Calhoun, Paul Price and Ashley Timmer (eds), Understanding September 11, New York: The New Press, p. 102.

${ }^{51}$ Milke Featherstone (2003), "Islam Encountering Globalization: An Introduction" in Ali Mohammedi (ed), Islam Encountering Globaliqation, London: IB Tauris, Pp. 3-4. 
Ethnic and religious differences and rivalries may not be all-explaining paradigm or system of coordinates for all territorial confrontations, economic rivalies and power interests, but they do constitute the permanent underlying structures by which political, economic, and military conflicts bave from time immemorial been justified, inspired, and dramatized, as well as defused and settled. ... The allegedly inevitable global clash of civilizations can at best serve as new wellspring of fear as required by certain military strategies. But the fonvard-looking vision for bumanity is different: global peace between the religions and cultures, into which we must put all our energy and wbich is a prerequisite and engine for global peace between nations. ${ }^{52}$

\section{G. Concluding Remarks}

The terrorist attacks on New York and Washington and the American government's unilateralist behaviour since provide an opportunity for international society to teflect, re-examine its past practices in a consensual manner, and come up with new initiatives and strategies for strengthening global governance and reducing the likelihood of terror ${ }^{53}$ In this context, instead of promoting a clash of civilizations and deploying a unilateral, militaristic approach in combating terrorism, more attention and energy should be devoted in addressing the ethical and justice issues posed by the global polarization of wealth, income, and power and with them the huge asymmetries of life chances by connecting the project of economic globalization to manifest principles of social justice. ${ }^{54}$

At the same time, the need for a deeper understanding between Islam and the West and the call for a closer 'dialogue between civilizations' should be situated in the global effort of creating a more just world order embracing a world of unusual cultural differences and unprecedented global inequalities. On this Samir Amin has reminded us that "there is no possibility of a united front against terrorism. Only the development of a unified front against international and social injustice can serve to make such desperate acts of victims of the system useless on their part and no longer possible". ${ }^{55}$ Esack makes the argument strongger by suggesting that within the context of the enormous injustice suffered by people all over the world today, a far greater requirement than inter - faith and cross - cultural dialogue in the wotld today is inter - faith and cross - cultural solidarity for a just and human world "where

${ }^{52}$ Hans Kung (1999), "Inter-Cultural Dialogue versus Confrontation" in Henrik Schmieglow (ed), Preventing the Clash of Civilizations: $A$ Peace Strategy for the Twenty-First Century, New Yotk: St. Martin's Press, pp. 102-103.

${ }^{53}$ Samuel M. Makinda (2003), "Global Governance and Terrorism" in Global Change Peace of Security, Vol. 15, No. 1, February, p. 58.

${ }^{3}$ David Held, op. cit., p. 102.

${ }^{53}$ Samir Amin (2001), "US Hegemony and Response to Terror" in Montbly Review, November, p. 53 
people are judged by their deeds and not by theit ethnic, religious or sexual label: in brief, a world of justice". ${ }^{56}$

\section{BIBLIOGRAPHY}

Abdullahi Ahmed An-Na'im (2002), "Upholding International Legality Against Islamic and Ametican Jihad" in Ken Booth and 'Tim Dunne (eds), Worlds in Collision: Terror and the Future of Global Order, New York: Palgrave McMillan. Archibugi, Daniele and Irish Marion Young (2003), "Envisioning A Global Rule of Law" in James P. Sterba (ed), Terrorism and International Justice, New York: Oxford University Press.

Armstrong, Karen (2000), Islam: $A$ Short History,London: Weidenfeld and Nicolson Aziz Al-Azmeh (1993), Islams and Modernities, London, New York: Verso.

Bassam Tibi (1998), The Challenge of Fundamentalism: Political Islam and The New World Disorder, Barkeley: University of California Press.

Buck-Morss, Susan (2003), Can There Be a Global Left? Thinking Past Terror, London, New York: Verso.

Eickelman, Dale F. and James Picastoti (1996), Muslim Politics, Princeton: Princeton University Press.

Esack, Farid (2003), "In Search of Progressive Muslims After 911" in Omid Safi (ed), Progressive Muslims on Gender, Pluralism and Justice, Oxford: One World Publisher.

Esposito, John L (1996), Islam: The Straight Path, Oxford, New York: Oxford University Press.

Esposito, John L. and John A. Voll (1996), Islam and Democracy, New York and Oxford: Oxford University Press.

(2000), "Islam and the West: Muslim Voices of Dialogue", in Millenium:Journal of International Studies, Vol. 29, No. 3.

(2003), 'Islam and Civil Society' in John L.. Esposito and Francois Burgat (eds), Modernizing Islam: Religion and the Public Sphere in the Middle East and Europe, London: Hurst\&Company.

Faksh, Mahmud A. (1997), The Future of Islam in the Middle East, London: Praeger Featherstone, M. (2003), "Islam Encountering Globalization: An Introduction" in Ali Mohammedi (ed.), Islam Encountering Globalization, London: IB Tauris.

${ }^{56}$ Farid Esack (1999), On Being Muslim: Finding $A$ Religious Path in the World Todoy, One World Publicatin, p. 152. 
Fukuyama, Francis (2002), "History and September 11" in Ken Booth and Tim Dunne (eds), Worlds in Collision: Terror and the Future of Global Order, New York: Palgrave McMillan.

Haat, Gerrie ter (2002), "Religious Fundamentalism and Social Change: A Comparative Perspective" in Gerrie ter Haar and James J. Busuttil (eds.), The Freedom to Do God's Will: Religious Fundamentalism and Social Change, London, New York: Routledge.

Halliday, Fred (2000), “Global Governance: Prospects and Problems" in David Held and Anthony McGrew (eds), The Global Transformation Reader, Malden, MA: Blackwell Publisher.

Hefner, Robert, (ed.) (2005), Remaking Muslim Politics, Princeton: Princeton University Press.

Held, David (2002), "Violence, Law and Justice in A Global Age" in Craig Calhoun, Paul Price and Ashley Timmet (eds), Understanding September 11, New Yotk: The New Press.

Hopwood, Derek (1998), "Introduction: The Culture of Modemity in Islam and the Middle East" in John Cooper; Ronald L. Nettler, and Mohamed Mahmud (eds.), Islam and Modernity: Muslim Intellectuals Respond, London: IB Tauris.

Huntington, Samuel P. (1993), "The Clash of Civilizations?" in Foreign Affairs, Vol 72 No 3 , Summer.

Ibrahim Abu Rabi (1996), Intellectual Origins of Islamic Resurgence in the Modern Arab World, New York: State University of New Yotk Press.

Ismail, Salwa (2003), Rethinking Islamist Politics, Culture, the State and Islamism, London: IB Tauris.

Khaled Abou el-Fadl (2002), "The Orphan of Modemity and the Clash of Civilizations" in Global Dialogue, Vol. 4, No. 2, Spring.

Kung, Hans (1999), "Inter-Cultural Dialogue versus Confrontation" in Henrik Schmieglow (ed), Preventing the Clash of Civilizations: A Peace Strategy for the Twenty-First Century, New York: St. Martin's Press.

Lawtence, Bruce B. (1998), "From Fundamentalism to Fundamentalisms: A Religious Ideology in Multiple Forms" in Paul Heelas (ed.), Religion, Modernity and Postmodernity, Oxford: Blackwell Publisher.

Lawrence, Bruce B. (1998), Shattering the Myth: Islam beyond Violence, Princeton: Princeton University Press.

(2003), Islam and the Myth of Confrontation: Religion and Politics in the Middle East, London: IB Tauris.

Mahmood Mamdani (2004), Good.Muslims, Bad Muslims: America, the Cold War and the Roots of Terror, New York: Pantheon Book.

Mahmood Monshipoury (2003), "The Semptember 11 Tragedy and the Muslim 
World: Living with Memory and Myth" in Journal of Church and State, Waco: Winter, Vol. 45. 1.

Makinda, Samuel M. (2003), "Global Governance and Terrorism" in Global Change Peace \& Security, Vol. 15, No. 1, February.

Nacos, Brigitte (2003), "The Terrorist Calculus Behind 9-11: A Model for Future Terrorism", Studies in Conflict and Terrorism.

Parekh, Bikhu (2002), "Terrorism or Intercultural Dialogue" in Ken Booth and Tim Dunne (eds), Worlds in Collision: Terror and the Future of Global Order, New York: Palgrave McMillan.

Saf6, Omid (2003), "Introduction: The times they are changin' - a Muslim quest for justice, gender equality and pluralism" in Omid Safi (ed), Progressive Muslims on Justice, Gender and Pluralism, Oxford: One World Publication.

Said, Edward (2002), "Impossible Histories: Why the many Islam cannot be simpliEled" in Harper's Magazine, July.

Salter, Mark B. (2000), Barbarians and Civilizations in International Relations, London: Sami Zubaida (1986), Islam, the People and the State, London: Routledge. "

Samir Amin (2001), "US Hegemony and Response to Terror" in Monthly Review, November.

Talal Asad (1983), "Ideology, Class and the Origin of the Islamic State" in Economy and Society, Vol. 9, No. 4, November.

Tariq Ali (2002), The Clash of Fundamentalisms, London: Verso.

Tumet, Bryan (ed) (1990), Theories of Modernity and Postmodernity, London: Sage Publication.

Voll, John O. (1987), "Islamic Renewal and the "Failure of the West", in Richard T. Antoun and Mary Elaine Hegland (eds.), Religious Resurgence: Contemporary Cases in Islam, Christianity and Judaism, Syracuse, New Yotk: Syracuse University Press. (1991), "The Heritage of Islamic Revival" in Yvonne Yazbeck Haddad, et. all, The Contemporary Islamic Revival, New York, Westport: Greenwood Press.

Waardenburg, Jacques (2002), Islam: Historical, Social and Political Perspective, Berlin and New York: Walter de Gțuyter.

Yvonne Yazbeck Haddad (1991), "The Revivalist Literature and the Literature on the Revival: An Introduction" in Yvonne Yazdeck Haddad et. all, The Contemporary Islamic Retival, New York, Westport: Greenwood Press. 